\title{
Assessing the effects of water withdrawal for hydraulic fracturing on surface water and groundwater - a review
}

\author{
Gopal Chandra Saha
}

Wilfrid Laurier University, 75 University Ave W, Waterloo, ON, Canada, e-mail: gsaha@wlu.ca

Michael Quinn

Mount Royal University, 4825 Mt Royal Gate SW, Calgary, AB, Canada

\section{Abstract}

The interaction between groundwater and surface water plays an important role in the function of riparian ecosystems and sustainable water resource management. Hydraulic fracturing, an unconventional oil and gas well stimulation method, has increased dramatically in North America in an effort to exploit previously inaccessible shale oil and gas reserves. Hydraulic fracturing often requires several thousand cubic meters of water to fracture the source formations. Use of such a high volume of water has raised considerable public concern over the sustainability of this activity and the potential impacts on surface water and groundwater. This paper provides a review of the published literature addressing the effects of water withdrawal for hydraulic fracturing on surface water and groundwater. The potential effects of such withdrawal are: decreased volume of water in rivers, streams, lakes and aquifers; alteration of natural flow regimes; regional water shortages during periods of drought; creating conflicts with other water users in water-stressed regions; inadequate downstream water availability; reduced downstream water quality for human uses, due to less water availability for dilution; and degradation of habitat and aquatic ecosystem function, impacting local wildlife. This review demonstrates that relatively little attention has been paid to quantify and understand these interactions, and suggests that there is a significant need for further research in this area to address the currently limited availability of data.

Keywords

Groundwater, surface water, hydraulic fracturing, water withdrawal, shale oil and gas production.

Submitted 5 April 2020, revised 12 November 2020, accepted 7 December 2020

DOI: $10.26491 / \mathrm{mhwm} / 131229$

\section{Introduction}

The interaction between groundwater and surface water is a significant component of the function of riparian ecosystems and sustainable water resources management (Kalbus et al. 2006). During wet periods, surface water can recharge groundwater, and during dry periods, groundwater provides a major source of water to the surface water flow. Therefore, groundwater and surface water are closely linked components of the hydrologic system. The development and utilization of any one component can affect the other, hence it is essential to understand and quantify the exchange processes between these two components for developing sustainable water resources management plans (Sophocleous 2002; Su et al. 2018).

Multi-stage hydraulic fracturing is an unconventional oil and gas well stimulation method of shale oil and gas production (ALL Consulting 2012). In most cases, water is used in hydraulic fracturing to 'frack' the geologic 
formations due to its efficiency, availability and low-cost. This technique facilitates extraction of oil and gas from vast shale reserves, which were previously considered inaccessible or unprofitable (Entrekin et al. 2011). In hydraulic fracturing, a fluid, either a liquid (most often water) or a gas, is pumped down with a suspended proppant (usually sand or ceramic beads) and additives (various chemicals which increase the performance of the fluid) under high pressure into the well, to cause the surrounding rock to fracture or crack (Oil and Gas Info 2019). When fracture pressures are abated, the proppant remains to keep the fractures open and allow oil and gas to be produced in the well. Figure 1 shows a schematic diagram of a hydraulically fractured well with horizontal drilling, where water is abstracted from surface water and groundwater sources for hydraulic fracturing. The volume of water used as fracturing fluid by the oil and gas industry varies significantly depending on the geological context. For example, in the Upper Peace Region of northwestern Alberta, Canada, the average water use per well was 3,671 $\mathrm{m}^{3}$ in 2013-2014 (Saha 2016). In 2016, the median water use per well in the Marcellus region (Pennsylvania and West Virginia) and the Permian Basin (Texas and New Mexico) was $27,950 \mathrm{~m}^{3}$ and $42,500 \mathrm{~m}^{3}$, respectively (Kondash et al. 2018). Meanwhile the average water consumption per well in the Vaca Muerta Play, Argentina in 2016, was 22,538 $\mathrm{m}^{3}$ (Rosa, D’Odorico 2019). Furthermore, in 2011-2017, the median water use per well in the Weiyuan play of the Sichuan Basin, China, was 36,014 $\mathrm{m}^{3}$

(Wu et al. 2019).

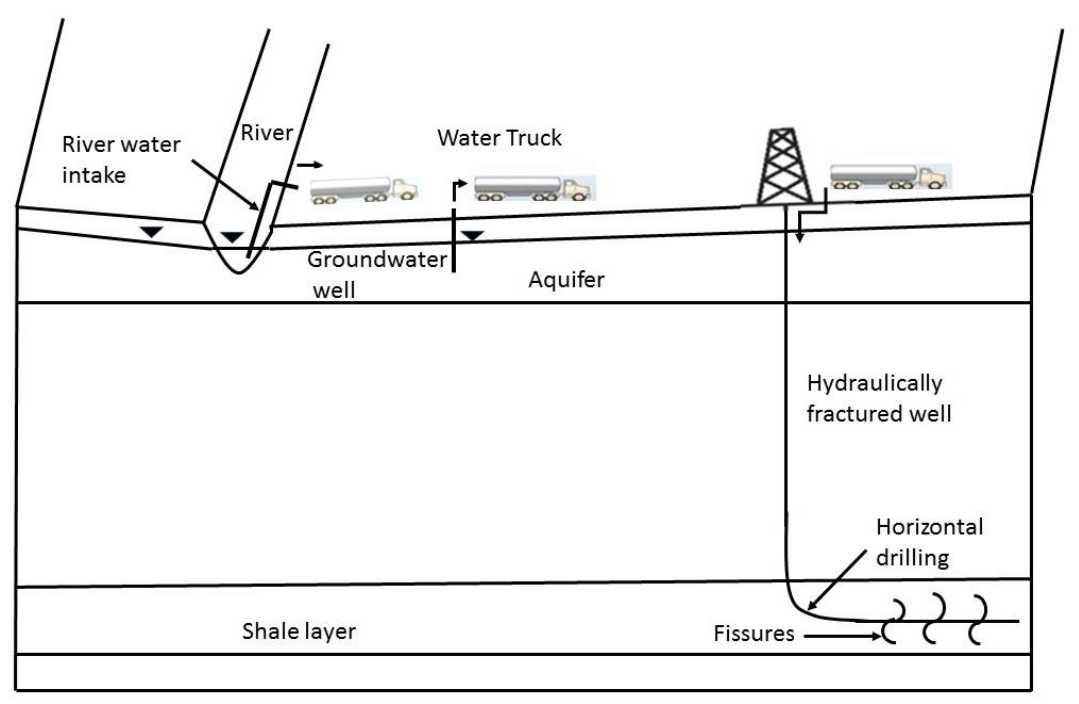

Fig. 1. A schematic diagram of a hydraulically fractured well with horizontal drilling, and water collection from surface water and groundwater sources for hydraulic fracturing. Figure is not drawn to a scale.

Although multi-stage hydraulic fracturing reduces the amount of natural landscape disturbance per well compared to conventional vertical drilling (ALL Consulting 2012), there is considerable public concern regarding the sustainability of this activity, because of its requirement for large volumes of water and given limited water 
resources (e.g. groundwater and surface water). Most often, the water is collected from surface water (i.e. rivers, lakes and wetlands), groundwater, or a combination of both. As a result, there is a need to understand the interaction between groundwater and surface water following water withdrawal for hydraulic fracturing. The objectives of this review are: a) to understand how the interaction between groundwater and surface water are affected by the impacts of water withdrawal for hydraulic fracturing, based on previously published literature, and; b) to identify future potential research in this area, required to better understand and quantify these interactions and to develop sustainable water resources management plans in shale gas and oil play regions.

\section{Materials and methods}

Firstly, a search for relevant previously published literature in Google Scholar was completed, using the phrase "The effects of hydraulic fracturing on" with a variety of other keywords, such as "groundwater-surface water (GW-SW) interaction, stream flow, groundwater flow, stream water level, and groundwater table". Only publications written in the English language were considered during the review process. Secondly, the results of each publication (i.e. qualitative and quantitative) was reviewed, selecting publications that highlighted the effects of water withdrawal for hydraulic fracturing on either stream flow, groundwater table, environmental flow or surface water and groundwater availability. In total, 29 suitable publications were identified (stream flow (18), groundwater table (7), environmental flow (2), and surface water and groundwater availability (2)). In addition, publications which highlighted other environmental issues associated with hydraulic fracturing have been cited as part of this review, to demonstrate the comprehensive negative impacts of hydraulic fracturing on the environment, society and human health.

\section{Results and discussion}

\subsection{Surface water and groundwater changes, under the effects of water withdrawal for hy- draulic fracturing}

Since 2010, the concerns related to hydraulic fracturing have been focused on various environmental issues, such as stray gas migration to shallow groundwater (Osborn et al. 2011; Vengosh et al. 2014) and to the atmosphere (Howarth et al. 2011), possible hydraulic connectivity between deep shale formations and shallow aquifers (Warner et al. 2012), water use (Nicot, Scanlon 2012; Carlson, Stelfox 2014), air quality (Colborn et al. 2014), seismicity (Holland 2011; Keranen et al. 2014), and the potential for contamination from hydraulic fracturing fluid and/or produced brines containing toxic substances during drilling, transport, and disposal (Dresel, Rose 2010; Rowan et al. 2011; Gregory et al. 2011). The results from these studies revealed that hydraulic fracturing has the potential for pollution of surface water, groundwater and the air, for causing earthquakes, creating conflict among competing water users and health related issues. Among these identified impacts, the potential for pollution of surface water and groundwater due to hydraulic fracturing has been paramount in public discourse and peer-reviewed journal articles (Osborn et al. 2011; Myers 2012; Barbot et al. 
2013; Fontenot et al. 2013; Gordalla et al. 2013; Olmstead et al. 2013; Vengosh et al. 2013; Vidic et al. 2013; Warner et al. 2013; Brittingham et al. 2014; Vengosh et al. 2014; Gallegos, Varela 2015; Kuwayama et al. 2015). A moderate number of articles qualitatively addressed the potential impacts of hydraulic fracturing on water resources due to extensive water withdrawal from nearby water sources (Kargbo et al. 2010; Entrekin et al. 2011; Brittingham et al. 2014; Vengosh et al. 2014; Gallegos, Varela 2015; Kuwayama et al. 2015), and the combined effects of this withdrawal with other activities related to hydraulic fracturing (Rahm, Riha 2012). The potential impacts from such withdrawal include: decreased volumes of water in rivers, streams, lakes and aquifers (Rahm, Riha 2012; Brittingham et al. 2014; Vengosh et al. 2014; Gallegos, Varela 2015; Kuwayama et al. 2015); alteration of natural flow regimes (Entrekin et al. 2011; Rahm, Riha 2012; Brittingham et al. 2014); regional water shortages during periods of drought (Entrekin et al. 2011; Vengosh et al. 2014); creating conflicts among competing users in regions of water-stress (Cooley, Donnelly 2012); inadequate downstream water availability (Entrekin et al. 2011; Rahm, Riha 2012); reduced quality of water downstream for human use, due to less water availability for dilution (Entrekin et al. 2011; Brittingham et al. 2014; Vengosh et al. 2014) and; degradation of habitat (Rahm, Riha 2012; Brittingham et al. 2014) and aquatic ecosystem function (Kargbo et al. 2010; Entrekin et al. 2011; Brittingham et al. 2014), essential for wildlife. Very few studies/articles were found that quantified the impacts of water withdrawal for hydraulic fracturing, representing a significant gap in the literature.

Due to the importance of water resources, quantifying the effects of water withdrawal for hydraulic fracturing has received increased research attention over the last 7 years. The variables assessed in the selected literature included the impacts on annual stream flow (Cothren et al. 2013; Best, Lowry 2014; Sharma et al. 2015), daily stream flow (Shank, Stauffer 2015; Barth-Naftilan et al. 2015; Sullivan et al. 2015), monthly stream flow (MacQuarrie 2018; Entrekin et al. 2018), stream low flow (Sharma et al. 2015; Shrestha et al. 2016; Lin et al. 2018), environmental stream flow components (i.e. high flow, low flow and extremely low flow) (Cothren et al. 2013; Buchanan et al. 2017), annual surface water and groundwater availability (Sullivan et al. 2015; Vandecasteele et al. 2015), and annual groundwater table/level (Best, Lowry 2014; Sullivan et al. 2015; Lin et al. 2018). Studies were primarily conducted using: hydrological models, such as the SWAT (Soil and Water Assessment Tool) model (Cothren et al. 2013; Sharma et al. 2015; Shrestha et al. 2016) and the MODFLOW (Modular 3Dimensional Finite-Difference Groundwater Flow) model (Best, Lowry 2014); regression models, such as the CIRF (Conditional Inference Random Forest) model (Buchanan et al. 2017); or a range of indices such as a withdrawal index (Shank, Stauffer 2015; Barth-Naftilan et al. 2015), surface water use intensity index (Sullivan et al. 2015; MacQuarrie 2018; Entrekin et al. 2018) or water exploitation index (Vandecasteele et al. 2015).

Based on the search and review of the published literature, quantitative research most commonly focused on the impacts of water withdrawal for hydraulic fracturing on surface water. Of these, most studies considered surface water withdrawal from streams only, the key findings of which are presented in Table 1. Overall, these 
studies found that the total amount of water withdrawal for hydraulic fracturing was very low compared to stream flow. The magnitude of this proportion varied inversely with stream size (i.e. order) and watershed area. For example, Shank and Stauffer (2015) found daily water withdrawal for shale gas development ranged from $0.04 \%$ to $6.8 \%$ of average daily flow in the Susquehanna River Basin $\left(71,251 \mathrm{~km}^{2}\right)$, United States of America (USA), with the largest values associated with the headwater (i.e. upstream or lower order) streams, because of the relatively lower stream flow compared to that of higher order streams (i.e. downstream). Sullivan et al. (2015) also found similar results in the Susquehanna River Basin, USA. Barth-Naftilan et al. (2015) found daily permitted water withdrawal was less than $5 \%$ of median flow of streams that lie within comparatively large watersheds $\left(>1000 \mathrm{~km}^{2}\right)$ in Pennsylvania’s Marcellus Shale Play, USA. Meanwhile, MacQuarrie (2018) found monthly water withdrawal for shale gas development was $6 \%$ of mean monthly stream flow during winter months (November-February) in a sub-basin $\left(835 \mathrm{~km}^{2}\right)$ of the Duvernay Formation (approximately 130,000 $\mathrm{km}^{2}$ ) in Alberta, Canada, while for other sub-basins with larger areas, that value was lower. Furthermore, Cothren et al. (2013) found the water quantity used for hydraulic fracturing was approximately $0.05 \%$ of the overall discharge of the study area $\left(127,300 \mathrm{~km}^{2}\right)$ in the Fayetteville Shale Play in Arkansas, USA. Therefore, the effects of water withdrawal for hydraulic fracturing on stream flow depend not only proportionally on the amount of water withdrawn, but also inversely on the stream size and watershed area. In addition, the effects of water withdrawal for hydraulic fracturing on stream flow depends on the temporal and spatial stream flow in the watershed. For example, Cothren et al. (2013) found no difference between the annual water balance components of the baseline scenario (with no water withdrawn for hydraulic fracturing) and the generated scenarios (with water withdrawn for hydraulic fracturing) at basin scale $\left(127,300 \mathrm{~km}^{2}\right)$ in the Fayetteville Shale Play in Arkansas, USA. However, on the monthly time-step and sub-basin scale, they found significant changes in stream flow during low flow months. Sharma et al. (2015) found at the local scale (i.e. sub-basin), water withdrawal from streams had little (less than 1.5\%) impact on mean seasonal and annual flow in the Muskingum watershed $\left(20,720 \mathrm{~km}^{2}\right)$ of eastern Ohio, USA. However, modest impacts were found on the 7-day minimum monthly flow (low flow), especially at the local scale and in lower order streams, which had a variable impact between $5.2 \%$ and $10.6 \%$, in comparison to baseline and generated scenarios. They also found the impacts of water withdrawal from streams is greater on the 7-day minimum monthly flow than on the mean monthly, seasonal and annual stream flow, because of the lower value of the 7-day minimum monthly flow. In the same watershed, Shrestha et al. (2016) found that the headwater streams in the sub-watersheds were heavily affected, with significant decrease in 7-day low flow. Best and Lowry (2014) found under the maximum density of well development, stream flow was reduced by up to $13 \%$ in a localized region with narrow valleys and streams with lower annual discharge, whereas stream flow reduction still remained under 3\% throughout most of the stream network in a study area $\left(3,390 \mathrm{~km}^{2}\right)$, in the Marcellus Shale 
Play in New York, USA. Entrekin et al. (2018) found estimated daily water usage for hydraulic fracturing exceeded the monthly low-flow withdrawal threshold in $48-79 \%$ of the catchments (mainly in smaller catchments) during dry months (June-November) in 2011-2014, in the Fayetteville Shale Play (total area: 127,300 $\mathrm{km}^{2}$, consists of catchments ranged in size from 47 to 1,959 $\mathrm{km}^{2}$ ) in Arkansas, USA. Lin et al. (2018) found during low flow conditions, the small-to-medium sized streams in the Bakken Shale Play $\left(35,000 \mathrm{~km}^{2}\right)$ in North Dakota, USA, had more stream flow during 2008-2014 than 2000-2007, due to greater rainfall than normal. Therefore, the Bakken Shale Play oil development had little impact on stream flow. Using a water exploitation index, Vandecasteele et al. (2015) evaluated the potential impacts of shale gas development in northern Poland. They found that in 2028 under the high scenario (i.e. water consumption per well 19,000 $\left.\mathrm{m}^{3}\right), 0.83 \%$ of the hydraulic fracturing water would come from surface water, while $22.42 \%$ would come from groundwater sources. It was concluded that water for shale gas extraction in northern Poland should be withdrawn from surface waterbodies, in order to reduce stress on groundwater. Alternatively, in 2011, Sullivan et al. (2015) found $77.5 \%$ and $21.9 \%$ of hydraulic fracturing water was taken from surface water (i.e. rivers and stream) and groundwater, respectively, in the Susquehanna River Basin, USA. It indicated that groundwater should be used for hydraulic fracturing to reduce impact on surface water in this basin.

Table 1. The key findings from the quantitative studies related to the impacts of water withdrawal for hydraulic fracturing on water resources.

\begin{tabular}{|c|c|}
\hline Key finding & Justification \\
\hline $\begin{array}{l}\text { The effects of water withdrawal from } \\
\text { streams for hydraulic fracturing on stream } \\
\text { flow are dependent not only proportionally } \\
\text { on the volume of water withdrawn, but } \\
\text { also inversely on stream size and watershed } \\
\text { area. }\end{array}$ & $\begin{array}{l}\text { Shank and Stauffer (2015) found that daily water withdrawal ranged from } 0.04 \% \\
\text { to } 6.8 \% \text { of average daily flow in the Susquehanna River Basin }\left(71,251 \mathrm{~km}^{2}\right) \text {, } \\
\text { USA. The largest values are associated with the headwater (i.e. upstream or } \\
\text { lower order) streams, and vice versa. Barth-Naftilan et al. (2015) found daily } \\
\text { permitted water withdrawal were less than } 5 \% \text { of median flow of streams in the } \\
\text { comparatively large watersheds }\left(>1000 \mathrm{~km}^{2}\right) \text { in Pennsylvania's Marcellus Shale } \\
\text { Play, USA. Similar results were found in Cothren et al. (2013), and MacQuarrie } \\
\text { (2018). }\end{array}$ \\
\hline $\begin{array}{l}\text { The effects of water withdrawal from } \\
\text { streams for hydraulic fracturing on stream } \\
\text { flow are dependent on both temporal and } \\
\text { spatial components of stream flow in the } \\
\text { watershed. }\end{array}$ & $\begin{array}{l}\text { Cothren et al. (2013) did not find any difference between the annual water bal- } \\
\text { ance components of the baseline scenario (with no withdrawal of water for hy- } \\
\text { draulic fracturing) and the generated scenarios (with water withdrawn for hy- } \\
\text { draulic fracturing) at basin scale }\left(127,300 \mathrm{~km}^{2}\right) \text { in the Fayetteville Shale Play, in } \\
\text { Arkansas, USA. However, they found significant changes in stream flow during } \\
\text { low flow months on the monthly time-step and sub-basin scale. Sharma et al. } \\
\text { (2015) found that at the local scale (sub-basin), water withdrawal from streams } \\
\text { had little }(<1.5 \%) \text { impact on mean seasonal and annual flow in the Muskingum } \\
\text { watershed }\left(20,720 \mathrm{~km}^{2}\right) \text { of eastern Ohio, USA. However, modest (5.2\% to } \\
10.6 \%) \text { impacts were found on the } 7 \text {-day minimum monthly flow (low flow) es- } \\
\text { pecially at the local scale and in lower order streams, in comparison with base- } \\
\text { line and generated scenarios. Similar results were found in Best and Lowry } \\
\text { (2014), Shrestha et al. (2016), and Entrekin et al. (2018). }\end{array}$ \\
\hline
\end{tabular}




\begin{tabular}{|c|c|}
\hline $\begin{array}{l}\text { The effects of water withdrawal from } \\
\text { streams for hydraulic fracturing on envi- } \\
\text { ronmental flow of lower order streams } \\
\text { with small watersheds are significant during } \\
\text { low flow periods. }\end{array}$ & $\begin{array}{l}\text { Buchanan et al. (2017) found under the least intense withdrawal scenario (i. e. } \\
\left.\text { daily water withdrawal } 1,210 \mathrm{~m}^{3}\right) 21 \% \text { of reference headwaters and creeks } \\
\left(\text { drainage areas less than } 99 \mathrm{~km}^{2}\right) \text { experienced approximately } 50 \% \text { reduction in } \\
\text { stream flow during low-flow periods in the Marcellus Shale formation (170,000 } \\
\left.\mathrm{km}^{2}\right) \text {, USA, whereas for larger rivers, little change was found. Cothren et al. } \\
(2013 \text { ) also found stream flow decreased during November } 2007 \text { and January } \\
2008 \text { (low flow months) by } 34 \% \text { and } 67 \% \text {, respectively, in one of the sub-basins } \\
\text { with a large number of wells located upstream in the Fayetteville Shale Play, in } \\
\text { Arkansas, USA. Similar results were found by Shrestha et al. (2016) in the head- } \\
\text { water streams in the sub-watersheds of the Muskingum watershed, USA. }\end{array}$ \\
\hline $\begin{array}{l}\text { The effects of water withdrawal from } \\
\text { groundwater for hydraulic fracturing on } \\
\text { groundwater level are local, and groundwa- } \\
\text { ter level decreases proportionally to the } \\
\text { amount of water withdrawal from the } \\
\text { groundwater pumping well. }\end{array}$ & $\begin{array}{l}\text { Best and Lowry (2014), Sullivan et al. (2015), Vandecasteele et al. (2015), and } \\
\text { Lin et al. (2018) found notable groundwater level decreases near the pumping } \\
\text { wells. }\end{array}$ \\
\hline
\end{tabular}

Water withdrawal from streams for hydraulic fracturing has significant effects on environmental flow (i.e. instream flow needs) of lower order streams with small watersheds, during periods of low flow. According to the Brisbane Declaration (2007), environmental flow is defined as "the quantity, timing, and quality of water flows required to sustain freshwater and estuarine ecosystems and the human livelihoods and well-being that depend on these ecosystems." Buchanan et al. (2017) revealed water withdrawal for shale gas development alters natural flow regimes, especially streams draining small watersheds (less than $99 \mathrm{~km}^{2}$ ) during low-flow periods in the Marcellus Shale formation $\left(170,000 \mathrm{~km}^{2}\right)$, USA. They found under the least intense withdrawal scenario (i. e. daily water withdrawal 1,210 $\mathrm{m}^{3}$ ) $21 \%$ of reference headwaters and creeks (drainage areas less than $99 \mathrm{~km}^{2}$ ) experienced approximately 50\% reduction in summer flow (low flow months), whereas for larger rivers little change was found. Cothren et al. (2013) found at one of the sub-basins with a large number of wells located upstream in the Fayetteville Shale Play in Arkansas, USA, stream flow decreased during November 2007 and January 2008 (low flow months) by 34\% and 67\%, respectively. Similar results were found in the headwater streams in the sub-watersheds of the Muskingum watershed, USA (Shrestha et al. 2016). Therefore, lower order streams in a smaller sub-basin (sub-watershed) are at greater risk to be impacted negatively by water withdrawal for hydraulic fracturing during intervals of low flow or water scarcity, such as during winter months or periods of drought (Vandecasteele et al. 2015; MacQuarrie 2018). Our searches revealed scant published literature on the impacts of water withdrawal for hydraulic fracturing on other types of surface water bodies, such as lakes or wetlands. Water withdrawal from such sources requires additional attention, as lakes and wetlands can ease the negative impact of flooding and droughts by storing large amounts of water which is then released during shortages. They also replenish groundwater, improve water quality of downstream watercourses, and preserve the biodiversity and habitat of the surrounding area.

Similarly, we found very little research on the impacts of water withdrawal for hydraulic fracturing on groundwater. Studies which did assess the effects on groundwater, found that groundwater level decreased locally and proportionally to the amount of water withdrawn from the groundwater pumping well (Best, Lowry 
2014; Sullivan et al. 2015; Vandecasteele et al. 2015; Lin et al. 2018). For example, Lin et al. (2018) found regional groundwater level decreased by $0.3-1.5 \mathrm{~m}$ in three shallow aquifers, where a large number of hydraulically fractured wells used groundwater from those aquifers during fracturing operation in the Bakken Shale Play, USA. However, one study using the MODFLOW model indicated that groundwater level (for the study area of 3,390 $\mathrm{km}^{2}$ ) did not experience any detectable change when water was withdrawn from the stream network (Best, Lowry 2014). This finding is likely a result of the coarser model resolution which consisted of 193 rows and 281 columns of $250 \mathrm{~m} \times 250 \mathrm{~m}$ cells. However, finer grid resolution (e.g. $10 \mathrm{~m}$ by $10 \mathrm{~m}$ grid cells) of the model domain could detect groundwater levels changes (i.e. declines) near to the surface water withdrawal locations.

Based on our literature search, very few research studies have used hydrological models to quantify the effects of water withdrawal on water resources. These studies often made a range of assumptions due to missing information (i.e. location of water withdrawal, type of water source, amount of water per well, and timing of water withdrawal), which are detailed in Table 2 . They simulated annual stream flow, stream low flow, environmental steam flow components (i.e. high flow, low flow and extremely low flow) and annual groundwater table/level under the influence of water withdrawal for hydraulic fracturing. On the other hand, studies which used regression models (e.g. CIRF model) simulated only environmental stream flow components (i.e. high flow, low flow and extremely low flow). Furthermore, studies which used a withdrawal index, surface water use intensity index, or water exploitation index, estimated the proportion of the water withdrawn from stream for hydraulic fracturing relative to the stream flow in relation to the orders of streams and the overall discharge of the study area.

Table 2. Assumptions made in hydrological models of reviewed studies due to missing information, to quantify the impacts of water withdrawal for hydraulic fracturing on water resources.

\begin{tabular}{|c|c|c|c|c|}
\hline Study & Type of water source & $\begin{array}{l}\text { Location of } \\
\text { water withdrawal }\end{array}$ & Amount of water per well & $\begin{array}{l}\text { Timing of } \\
\text { water withdrawal }\end{array}$ \\
\hline $\begin{array}{l}\text { Cothren et al. } \\
(2013)\end{array}$ & Stream (surface water) & $\begin{array}{l}\text { From the nearest stream } \\
\text { to each hydraulically } \\
\text { fractured well }\end{array}$ & $18,927.0 \mathrm{~m}^{3}$ & $\begin{array}{l}3,785.4 \mathrm{~m}^{3} \text { of water was } \\
\text { uniformly withdrawn } \\
\text { during } 5 \text { consecutive } \\
\text { months }\end{array}$ \\
\hline $\begin{array}{l}\text { Best, Lowry } \\
\text { (2014) }\end{array}$ & $\begin{array}{l}\text { Stream (surface water) } \\
\text { and groundwater }\end{array}$ & $\begin{array}{l}\text { For surface water with- } \\
\text { drawal: from the nearest } \\
\text { stream to each hydrau- } \\
\text { lically fractured well; For } \\
\text { groundwater withdrawal: } \\
\text { from the closest munici- } \\
\text { pal well and private well } \\
\text { to each hydraulically } \\
\text { fractured well }\end{array}$ & $11,356.2 \mathrm{~m}^{3}$ & $\begin{array}{l}\text { All water withdrawals } \\
\text { were distributed over the } \\
\text { entire year }\end{array}$ \\
\hline $\begin{array}{l}\text { Sharma et al. } \\
(2015)\end{array}$ & Stream (surface water) & No information reported & $\begin{array}{l}\text { The amount of water for } \\
\text { each hydraulically frac- } \\
\text { tured well reported in } \\
\text { www.fracfocus.org was } \\
\text { used for each hydrau- } \\
\text { lically fractured well }\end{array}$ & No information reported \\
\hline
\end{tabular}




\begin{tabular}{|c|c|c|c|c|}
\hline $\begin{array}{l}\text { Shrestha et al. } \\
\text { (2016) }\end{array}$ & Stream (surface water) & No information reported & $\begin{array}{l}\text { The amount of water for } \\
\text { each hydraulically frac- } \\
\text { tured well reported in } \\
\text { www.fracfocus.org was } \\
\text { used for each hydrau- } \\
\text { lically fractured well }\end{array}$ & No information reported \\
\hline
\end{tabular}

\subsection{Potential opportunities for future research}

This review has identified missing information and gaps in the current understanding of GW-SW interaction associated with the effects of water withdrawal for hydraulic fracturing. The following research areas are considered as potential opportunities for future study:

1. How the mechanism and quantity of water withdrawal from surface water (i.e. streams) and groundwater sources for hydraulic fracturing might affect groundwater discharge (i.e. base flow), surface water and groundwater levels, and groundwater contributions to stream flow in shale gas and oil play areas. In line with this, questions for consideration should include: What are the temporal patterns of those impacts throughout the year and what are the spatial patterns of those impacts in a shale gas and oil play area? Since previous studies have demonstrated that water withdrawal from streams has little impact on stream flow in comparatively large watersheds, further research should be done at a small scale (e.g. streams with small catchment areas) to better understand localized GW-SW interaction and quantify the impacts of water withdrawal from surface water (streams) and groundwater for hydraulic fracturing. In addition, models should use a finer grid resolution (e.g. $10 \mathrm{~m}$ by $10 \mathrm{~m}$ grid cells) to understand and visualize those impacts on groundwater level changes, near to the surface water withdrawal locations in stream.

2. What are the temporal and spatial patterns of the impacts of water withdrawal for hydraulic fracturing on other surface water bodies, especially lakes and wetlands?

3. What are the potential impacts of water withdrawal for hydraulic fracturing on other water users, such as agriculture, mining, manufacturing industries, municipal water supply, especially in regions with limited water resources?

4. Do we need to improve the definition of passby flow for lower order streams, especially during periods of low flow because the relative reduction in stream flow is higher in those streams due to water withdrawal? Passby flow is defined as the minimum stream flow that must be allowed to pass through a prescribed point of stream at any time, during which a water withdrawal is occurring from that point (Liu et al. 2018). When the natural flow is below the threshold passby flow at a prescribed point of stream, water withdrawal must be stopped from that point, and the entire natural flow must be allowed to pass through that point of stream.

5. Can pressure changes in hydraulic fracturing activate fracture connections to change flow to or from streams/lakes/wetlands, which might affect GW-SW interaction? This research should be conducted at a small scale to understand and quantify any variation. 
Addressing these questions would provide comprehensive information needed to develop regional water budgets, which will help regional water managers to develop sustainable water resources management plans in shale gas and oil play regions. For example, the temporal (i.e. monthly, seasonal, annual) changes in groundwater contributions to stream flow could determine the temporal status of groundwater resources and site conditions for groundwater-dependent terrestrial ecosystems (Naumburg et al. 2005). Determination of the monthly, seasonal and annual variations in the dependency of stream flow on groundwater, together with temporal surface water flow, would provide useful information to set monthly, seasonal and annual water extraction limits from the rivers, lakes and groundwater, and aid allocation to stakeholders for future water supply. In addition, a better understanding of GW-SW interactions will help water managers to take proper actions to maintain healthy aquatic and terrestrial ecosystems. For example, suspending water licenses for water withdrawal from local water sources during periods of low flow and drought, recycling water for hydraulic fracturing, promoting hydraulic fracturing during high flow and water level in rivers, streams and lakes, building water reservoirs, and encouraging the use of alternative fracturing fluids (e.g. frac oil; a combination of frac oil and nitrogen; a combination of frac oil and carbon dioxide, or; a combination of frac oil, acid water and hydrochloric acid) in regions with limited water resources during periods of low flow and drought.

The oil and gas industry currently uses a range of conservation practices for hydraulic fracturing to manage water resources, which mainly fall into three categories: 1) using lower quality water from non-traditional sources, 2) recycling and reusing produced and flowback waters, and 3) building infrastructure for transporting water (American Petroleum Institute 2017). Here, produced water means the water naturally present in the geologic formation, flowing to the surface along with oil and gas when those are pumped from the well (Freyman 2014), and flowback water refers to the water injected into the well as a fracturing fluid comes back to the surface after the end of hydraulic fracturing. The choice to use each practice(s) is based on a variety of factors, such as local water stresses, individual business needs, and the particular requirements for specific geologic formations. In Canada, the oil and gas industry uses deep saline and non-potable groundwater (Encana 2013), water reservoir and lined water storage pits (Chevron Canada 2019), water resource hub that recycle produced water (Encana 2013), water treatment plants (Encana 2019), recycling and reusing produced and flowback waters (BC Oil \& Gas Commission 2012). In the USA, recycling and reusing of produced and flowback waters is very common (U.S. Chamber of Commerce Foundation 2019), as well as buying effluent water from local municipalities (Freyman 2014).

There are significant challenges to overcome in order to address the identified research gaps. The major challenge results from limited data with which to assess the effects of water withdrawal for hydraulic fracturing on GW-SW interaction. For example, the limited number of groundwater monitoring wells and surface water monitoring gauges is one concerning issue. This problem is more significant in Canadian shale gas and oil play regions (i.e. Alberta and British Columbia) than in the USA. For example, in the Duvernay Formation 
(approximately 130,000 $\mathrm{km}^{2}$ ) in Alberta, Canada, there are publicly available records for only 60 active groundwater monitoring wells, accessible from Alberta provincial groundwater monitoring wells database (http://environment.alberta.ca/apps/GOWN/), and 10 surface water monitoring stations, which are maintained by the Water Survey of Canada (https://wateroffice.ec.gc.ca/).

In addition, monitoring stations of surface water bodies are primarily in streams and rivers, with very few in lakes and wetland areas. Furthermore, datasets that cover a wide spatial distribution of hydraulically fractured wells are not available for longer time periods (e.g. 10 years). For example, in the USA, this information has been available in the national hydraulic fracturing chemical registry called "fracfocus.org" since April 11, 2011 (United States Environmental Protection Agency 2015). Whereas in Canada, this data is accessible from a publicly available chemical disclosure registry called "fracfocus.ca" since January 1, 2012 in British Columbia, and December 19, 2012 in Alberta (Rivard et al. 2014). Another issue arises from a lack of data on the timing of water withdrawal for each well, the type of water source for hydraulic fracturing, and the locations of the water source in many shale gas and oil play regions. Having more comprehensive and readily available data would greatly assist in addressing the identified research gaps more accurately, through use of more detailed hydrological models.

Currently, there are no specific regulations in the USA or Canada specific to water withdrawal for hydraulic fracturing activities. Richardson et al. (2013) conducted a survey of regulations in 31 states where sources of shale gas and oil are available or might be available, and found that several states had discussed rules and restrictions for water withdrawal specific to shale gas and oil industry, however only in draft form. It was found that none had passed such legislation, and so these 31 states regulate water withdrawal (both surface water and groundwater) under general regulations. Meanwhile, 13 states (Texas, Utah, Colorado, Nebraska, Wyoming, Kansas, Oklahoma, New Mexico, California, Arkansas, Maryland, Pennsylvania and North Dakota) require water permits for all water withdrawal activities. 4 states (Michigan, New York, Georgia and New Jersey) require water permits only for water withdrawal over a specific threshold at $378.54 \mathrm{~m}^{3}$ per day or more. Similarly, Montana, South Dakota, Mississippi and Kentucky require permits over $190.78 \mathrm{~m}^{3}, 98.12 \mathrm{~m}^{3}, 75.70$ $\mathrm{m}^{3}$ and $37.85 \mathrm{~m}^{3}$ per day, respectively. Virginia has the highest threshold, requiring permits for water withdrawal of 1,135.62 $\mathrm{m}^{3}$ per day or more. More stringently, 3 states (Indiana, Ohio, and Vermont) require permit, registration and reporting over a specific threshold. While Indiana requires permit, registration and reporting of withdrawal over $378.54 \mathrm{~m}^{3}$ per day, Ohio and Vermont require registration and reporting for water withdrawal over $378.54 \mathrm{~m}^{3}$ and $75.70 \mathrm{~m}^{3}$ per day, respectively, but also require permits only when water withdrawal is more than 7,570.82 $\mathrm{m}^{3}$ and $218 \mathrm{~m}^{3}$ per day, respectively. West Virginia, Illinois, Alabama, Tennessee, and North Carolina do not require any permits, but mandate registration and reporting for water withdrawal for over $26.50 \mathrm{~m}^{3}, 378.54 \mathrm{~m}^{3}, 378.54 \mathrm{~m}^{3}, 37.85 \mathrm{~m}^{3}$ and $378.54 \mathrm{~m}^{3}$ per day, respectively. Comparably, Louisiana does not provide any permits, but requires registration and reporting for all water withdrawals. 
In Canada, there are also no water withdrawal regulations specific to hydraulic fracturing. For example, in Alberta and British Columbia where the majority of hydraulic fracturing activities occur, the oil and gas operators have to submit their water license applications along with their requested water demand for a specific year (e.g. in British Columbia 3 years projection period). The request for water demand will consider the numbers of wells to be completed in a specific period, how much water will be required, if there will be any recycling and which sources (i.e. groundwater and/or surface water) and locations will be used for hydraulic fracturing activities. The corresponding authorities (Alberta Energy Regulator in Alberta, and British Columbia Oil and Gas Commission in British Columbia) determine the outcome of applications depending on available water resources. Alternatively in Saskatchewan and Manitoba, water licenses are required for industrial activities when water withdrawal is over $4,933.92 \mathrm{~m}^{3}$, and $25 \mathrm{~m}^{3}$ per day, respectively.

\section{Conclusions}

This review discussed and evaluated the context and effects of water withdrawals for hydraulic fracturing on surface water and groundwater resources, based on previously published literature. It was found that water withdrawal for hydraulic fracturing has negative impacts on the volume of water resources, and that most of the quantitative research focused on surface water sources, particularly focusing on water withdrawal from streams only. The key findings of those quantitative studies include: 1) the effects of water withdrawal from streams for hydraulic fracturing on stream flow depend not only proportionally on the volume of water withdrawn, but also inversely on the stream size and watershed area; 2) the effects of water withdrawal from streams for hydraulic fracturing on stream flow depend on both temporal and spatial components of stream flow in the watershed; 3) during periods of low flow, water withdrawal from streams for hydraulic fracturing have significant effect on environmental flow of lower order stream in small watershed, and; 4) groundwater level decreases locally and proportionally to the volume of water withdrawn from the groundwater pumping well for hydraulic fracturing. This review also demonstrates that there is a lack of published research that quantifies changes in the GW-SW interaction under the effects of water withdrawal for hydraulic fracturing. Based on this, suggestions for further research are made, alongside identifying the current data limitations that constrain robust analysis. In particular, the effects of water withdrawal on lakes and wetlands during periods of low flow, and in areas of groundwater flow, require further investigation. Natural gas production using hydraulic fracturing is expected to increase globally to meet future energy demands. Given the extensive use of water, a much better understanding of the effects on watersheds and hydrologic function, is required. The development of sustainable water resource management plans calls for a much better understanding of GWSW interactions.

\section{References}

ALL Consulting, 2012, The modern practices of Hydraulic fracturing: a focus on Canadian resources, prepared for Petroleum Technology Alliance Canada and Science and Community Environmental Knowledge Fund, Tulsa, Oklahoma, 229 pp. 
American Petroleum Institute, 2017, Hydraulic fracturing. Unlocking America's natural gas resources, available online at https://www.api.org/ /media/Files/Oil-and-Natural-Gas/Hydraulic-Fracturing-primer/Hydraulic-Fracturing-Primer.pdf (data access 07.12.2020)

Barbot E., Vidic N.S., Gregory K.B., Vidic R.D., 2013, Spatial and temporal correlation of water quality parameters of produced waters from Devonian-age shale following hydraulic fracturing, Environmental Science \& Technology, 47 (6), 2562-2569, DOI: $10.1021 /$ es304638h

Barth-Naftilan E., Aloysius N., Saiers J.E., 2015, Spatial and temporal trends in freshwater appropriation for natural gas development in Pennsylvania's Marcellus Shale Play, Geophysical Research Letter, 42 (15), 6348-6356, DOI: 10.1002/2015GL065240

BC Oil \& Gas Commission, 2012, Water use in oil and gas activities. 2012 Annual Report., available online at https://www.bcogc.ca/files/reports/Technical-Reports/annual-water-report-2012.pdf (data access 07.12.2020)

Best L.C., Lowry C.S., 2014, Quantifying the potential effects of high-volume water extractions on water resources during natural gas development: Marcellus Shale, NY, Journal of Hydrology: Regional Studies, 1, 1-16, DOI: 10.1016/j.ejrh.2014.05.001

Brisbane Declaration, 2007, The Brisbane Declaration: environmental flows are essential for freshwater ecosystem health and human well-being, Declaration of the 10th International River symposium and International Environmental Flows Conference, Brisbane, Australia, 3-6 September 2007, available online at http://riverfoundation.org.au/wp-content/uploads/2017/02/THE-BRIS-

BANE-DECLARATION.pdf (data access 11.12.2020)

Brittingham M.C., Maloney K.O., Farag A.M., Harper D.D., Bowen Z.H., 2014, Ecological risks of shale oil and gas development to wildlife, aquatic resources and their habitats, Environmental Science \& Technology, 48 (19), 11034-11047, DOI: $10.1021 /$ es5020482

Buchanan B.P., Auerbach D.A., McManamay R.A., Taylor J.M., Flecker A.S., Archibald J.A., Fuka D.R., Walter M.T., 2017, Environmental flows in the context of unconventional natural gas development in the Marcellus Shale, Ecological Applications, 27 (1), 37 55, DOI: $10.1002 /$ eap.1425

Carlson M., Stelfox B., 2014, The cumulative effects of hydraulic fracturing in Alberta's eastern slopes, prepared for the project: CWN Hydraulic Fracturing and Water-Landscape Impacts, 40 pp.

Chevron Canada, 2019, Water management Chevron's approach to protecting this critical natural resource, available online at https:// canada.chevron.com/environment/water-management (data access 07.12.2020)

Colborn T., Schultz K., Herrick L., Kwiatkowski C., 2014, An exploratory study of air quality near natural gas operations, Human and Ecological Risk Assessment: An International Journal, 20 (1), 86-105, DOI: 10.1080/10807039.2012.749447

Cooley H., Donnelly K., 2012, Hydraulic fracturing and water resources: Separating the frack from the fiction, Pacific Institute, Oakland, CA, USA, 35 pp., available online at http://pacinst.org/wp-content/uploads/sites/21/2014/04/fracking-water-sources.pdf (data access 07.12.2020)

Cothren J., Thoma G., Diluzio M., Limp F., 2013, Integration of water resource models with Fayetteville Shale decision support and information system, Final Technical Report, University of Arkansas and Blackland Texas A\&M Agrilife, DE-FC2609FE0000804, 161 pp.,. available online at https://core.ac.uk/download/pdf/188994778.pdf (data access 07.12.2020)

Dresel P., Rose A., 2010, Chemistry and origin of oil and gas well brines in Western Pennsylvania, Pennsylvania Geological Survey, $4^{\text {th }}$ series Open-File Report OFOG 10-01.0; 48 pp.

Encana, 2013, 2013 Sustainability report, Calgary, Alberta, available at http://www.encana.com/pdf/sustainability/corporate/reports/sustainability-report-2013.pdf (07.12.2020)

Encana, 2019, Debolt facility provides alternative to surface water sources, available online at https://www.encana.com/news-stories/our-stories/environment-debolt-facility.html (data access 07.12.2020)

Entrekin S., Evans-White M., Johnson B., Hagenbuch E., 2011, Rapid expansion of natural gas development poses a threat to surface waters, Frontiers in Ecology and the Environment, 9 (9), 503-511, DOI: 10.1890/110053 
Entrekin S., Trainor A., Saiers J., Patterson L., Maloney K., Fargione J., Kiesecker J., Baruch-Mordo S., Konschnik K., Wiseman H., Nicot J.-P., Ryan J.N., 2018, Water stress from high-volume hydraulic fracturing potentially threatens aquatic biodiversity and ecosystem services in Arkansas, United States, Environmental Science \& Technology, 52 (4), 2349-2358, DOI:

10.1021/acs.est.7b03304

Fontenot B.E., Hunt L.R., Hildenbrand Z.L., Carlton D.D., Oka H., Walton J.L., Hopkins D., Osorio A., Bjorndal B., Hu Q.H., Schug K.A., 2013, An evaluation of water quality in private drinking water wells near natural gas extraction sites in the Barnett Shale formation, Environmental Science \& Technology, 47 (17), 10032-10040, DOI: 10.1021/es4011724

Freyman M., 2014, Hydraulic fracturing \& water stress: Water Demand by the Numbers- Shareholder, Lender \& Operator Guide to Water Sourcing, Ceres Report, available online at https://www.oilandgasbmps.org/viewpub.php?id=674 (data access 07.12.2020)

Gallegos T.J., Varela B.A., 2015, Trends in hydraulic fracturing distributions and treatment fluids, additives, proppants, and water volumes applied to wells drilled in the United States from 1947 through 2010 - Data analysis and comparison to the literature, U.S. Geological Survey Scientific Investigations, Report 2014-5131, 15 pp., available online at https://pubs.usgs.gov/sir/2014/5131/ (data access 07.12.2020)

Gordalla B.C., Ewers U., Frimmel F.H., 2013, Hydraulic fracturing: a toxicological threat for groundwater and drinking-water?, Environmental Earth Science, 70, 3875-3893, DOI: 10.1007/s12665-013-2672-9

Gregory K.B., Vidic R.D., Dzombak D.A., 2011, Water management challenges associated with the production of shale gas by hydraulic fracturing, Elements, 7, 181-186, DOI: 10.2113/gselements.7.3.181

Holland A., 2011, Examination of possibly induced seismicity from hydraulic fracturing in the Eola Field, Garvin County, Oklahoma, Oklahoma Geological Survey, Open-File Report, OF1-2011, 31 pp., available online at http://www.ogs.ou.edu/pubsscanned/openfile/OF1_2011.pdf (data access 07.12.2020)

Howarth R.W., Santoro R., Ingraffea A., 2011, Methane and the greenhouse-gas footprint of natural gas from shale formations, Climatic Change, 106, 679-690, DOI: 10.1007/s10584-011-0061-5

Kalbus E., Reinstorf F., Schirmer M., 2006, Measuring methods for groundwater-surface water interactions: a review, Hydrology and Earth System Science, 10, 873-887, DOI: 10.5194/hess-10-873-2006

Kargbo D.M., Wilhelm R.G., Campbell D.J., 2010, Natural gas plays in the Marcellus Shale: challenges and potential opportunities, Environmental Science \& Technology, 44, 5679-5684, DOI: 10.1021/es903811p

Keranen K.M., Weingarten M., Abers G.A., Bekins B.A., Ge S., 2014, Sharp increase in central Oklahoma seismicity since 2008 induced by massive wastewater injection, Science, 345 (6195), 448-451, DOI: 10.1126/science.1255802

Kondash A.J., Lauer N.E., Vengosh, A., 2018, The intensification of the water footprint of hydraulic fracturing, Science Advances, 4 (8), eaar5982, DOI: $10.1126 /$ sciadv.aar5982

Kuwayama Y., Olmstead S., Krupnick A., 2015, Water quality and quantity impacts of hydraulic fracturing, Current Sustainable Renewable Energy Reports, 2, 17-24, DOI: 10.1007/s40518-014-0023-4

Lin Z., Lin T., Lim S.H., Hove M.H., Schuh W.M., 2018, Impacts of Bakken Shale oil development on regional water uses and supply, Journal of the American Water Resources Association, 54 (1), 225-239, DOI: 10.1111/1752-1688.12605

Liu C., Zhang Z., Balay J.W., 2018, Posterior assessment of reference gages for water resources management using instantaneous flow measurements, Science of the Total Environment, 634, 12-19, DOI: 10.1016/j.scitotenv.2018.03.312

MacQuarrie A., 2018, Case study analysis on the impacts of surface water allocations for hydraulic fracturing on surface water availability of the Upper Athabasca River, Master's Thesis, Royal Roads University, 117 pp., available online at https://viurrspace.ca/handle/10613/5688 (data access 07.12.2020)

Myers T., 2012, Potential contaminant pathways from hydraulically fractured shale to aquifers, Groundwater, 50 (6), 872-882, 10.1111/j.1745-6584.2012.00933.x 
Naumburg E., Mata-Gonzalez R., Hunter R., Mclendon T., Martin D., 2005, Phreatophytic vegetation and groundwater fluctuations: A review of current research and application of ecosystem response modeling with an emphasis on Great Basin vegetation, Environmental Management, 35, 726-740, DOI: 10.1007/s00267-004-0194-7

Nicot J.P., Scanlon B.R., 2012, Water use for Shale - Gas production in Texas, U.S., Environmental Science \& Technology, 46 (6), 3580-3586, DOI: $10.1021 /$ es204602t

Oil and Gas Info, 2019, All about fracking, available online at https://oilandgasinfo.ca/all-about-fracking/ (data access 07.12.2020)

Olmstead S.M., Muehlenbachs L.A., Shih J., Chu Z., Krupnick A.J., 2013, Shale gas development impacts on surface water quality, [in:] Proceedings of the National Academy of Sciences of the United States of America, 10 (13), 4962-4967

Osborn S.G., Vengosh A., Warner N.R., Jackson R.B., 2011, Methane contamination of drinking water accompanying gas-well drilling and hydraulic fracturing, [in:] Proceedings of the National Academy of Sciences of the United States of America, 108 (20), 8172 8176

Rahm B.G., Riha S.J., 2012, Toward strategic management of shale gas development: regional, collective impacts on water resources, Environmental Science \& Policy, 17, 12-23, DOI: 10.1016/j.envsci.2011.12.004

Richardson N., Gottlieb M., Krupnick A., Wiseman H, 2013, The state of state shale gas regulation, Resources For The Future Report, available online at https://www.rff.org/publications/reports/the-state-of-state-shale-gas-regulation/ (data access 07.12.2020)

Rivard C., Lavoie D., Lefebvre R., Sejourne S., Lamontagne C., Duchesne M., 2014, An overview of Canadian Shale gas production and environmental concerns, International Journal of Coal Geology, 126, 64-76, DOI: 10.1016/j.coal.2013.12.004

Rosa L., D'Odorico P., 2019, The water-energy-food nexus of unconventional oil and gas extraction in the Vaca Muerta Play, Argentina, Journal of Cleaner Production, 207, 743-750, DOI: 10.1016/j.jclepro.2018.10.039

Rowan E., Engle M., Kirby C., Kraemer T., 2011, Radium content of oil- and gas-field produced waters in the northern Appalachian Basin (USA): summary and discussion of data, U.S. Geological Survey Scientific Investigations Report 513, 31 pp., DOI: $10.3133 / \operatorname{sir} 20115135$

Saha G.C., 2016, Investigation of temporal dynamics of hydraulic fracturing and water use: a case study from northwestern Alberta, Canada, [in:] Under Western Skies 2016, September 27-30, Calgary, Canada

Shank M.K., Stauffer Jr. J.R., 2015, Land use and surface water withdrawal effects on fish and macroinvertebrate assemblages in the Susquehanna River basin, USA, Journal of Freshwater Ecology, 30 (2), 229-248, DOI: 10.1080/02705060.2014.959082

Sharma S., Shrestha A., McLean C.E., Martin S.C., 2015, Hydrologic modelling to evaluate the impact of hydraulic fracturing on stream low flows: challenges and opportunities for a simulation study, American Journal of Environmental Sciences, 11 (4), 199 215, DOI: 10.3844 /ajessp.2015.199.215

Shrestha A., Sharma S., McLean C.E., Kelly B.A., Martin S.C., 2016, Scenario analysis for assessing the impact of hydraulic fracturing on stream low flows using the SWAT model, Hydrological Sciences Journal, 62 (5), 849-861, DOI:

10.1080/02626667.2016.1235276

Sophocleous M., 2002, Interactions between groundwater and surface water: the state of the science, Journal of Hydrogeology, 10, 5267, DOI: $10.1007 /$ s10040-001-0170-8

Su X.S., Cui G., Wang H., Dai Z.X., Woo Nam-Chil., Yuan W.Z., 2018, Biogeochemical zonation of sulfur during the discharge of groundwater to lake in desert plateau (Dakebo Lake, NW China), Environmental Geochemistry and Health, 40 (3), 1051-1066, DOI: $10.1007 /$ s10653-017-9975-9

Sullivan K., Cyterski M., Kraemer S., Knightes C., Price K., Kim K., Prieto L., Gabriel M., Sidle R., 2015, Case study analysis of the impacts of water acquisition for hydraulic fracturing on local water availability, U.S. Environmental Protection Agency, Washington, DC, EPA/600/R-14/179, available online at https://www.epa.gov/sites/production/files/2015-07/documents/hf_water_acquisition_report_final_6-3-15_508_km.pdf (data access 07.12.2020) 
U.S. Chamber of Commerce Foundation, 2019, Recycling water in hydraulic fracturing, available online at https://www.uschamberfoundation.org/recycling-water-hydraulic-fracturing (data access 07.12.2020)

United States Environmental Protection Agency, 2015, Analysis of Hydraulic Fracturing Fluid Data from the FracFocus Chemical Disclosure Registry 1.0, Office of Research and Development, Washington, DC, EPA/601/R-14/003, available online at https://www.epa.gov/hfstudy/analysis-hydraulic-fracturing-fluid-data-fracfocus-chemical-disclosure-registry-1-pdf (data access $07.12 .2020)$

Vandecasteele I., Marí Rivero I., Sala S., Baranzelli C., Barranco R., Batelaan O., Lavalle C., 2015, Impact of shale gas development on water resources: a case study in Northern Poland, Environmental Management, 55, 1285-1299, DOI: 10.1007/s00267-015-0454-8

Vengosh A., Warner N., Jackson R., Darrah T., 2013, The effects of shale gas exploration and hydraulic fracturing on the quality of water resources in the United States, Procedia Earth and Planetary Science, 7, 863-866, DOI: 10.1016/j.proeps.2013.03.213

Vengosh A., Jackson R.B., Warner N., Darrah T.H., Kondash A., 2014, A critical review of the risks to water resources from unconventional shale gas development and hydraulic fracturing in the United States, Environmental Science \& Technology, 48 (15), 8334-8348, DOI: $10.1021 /$ es405118y

Vidic R.D., Brantley S.L., Vandenbossche M., Yoxtheimer D., Abad J.D., 2013, Impact of shale gas development on regional water quality, Science, 340, 6134, DOI: 10.1126/science.1235009

Warner N.R., Christie C.A., Jackson R.B., Vengosh A., 2013, Impacts of shale gas wastewater disposal on water quality in Western Pennsylvania, Environmental Science \& Technology, 47(20), 11849-11857, DOI: 10.1021/es402165b

Warner N.R., Jackson R.B., Darrah T.H., Osborn S.G., Down A., Zhao K., White A., Vengosh A., 2012, Geochemical evidence for possible natural migration of Marcellus Formation brine to shallow aquifers in Pennsylvania, [in:] Proceedings of the National Academy of Sciences of the United States of America, 109 (30), 11961-11966, DOI: 10.1073/pnas.1121181109

Wu X., Xia J., Guan B., Yan X., Zou L., Liu P., Yang L., Hong S., Hu, S., 2019, Water availability assessment of shale gas production in the Weiyuan Play, China, Sustainability, 11 (3), 940, DOI: 10.3390/su11030940 